\title{
The Effectiveness of Web-Based Assessment on Student's Understanding of Concepts on Equilibrium and Rotation Dynamics
}

\author{
Neng Dyah Surya Pratama ${ }^{a}$ \\ Malang State Universty, Jl.Semarang 5 Malang, Indonesia

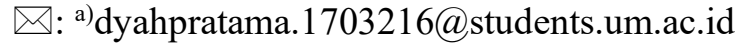

\begin{abstract}
This study aims to determine the effectiveness of using a web-based assessment on students' conceptual understanding of equilibrium and rotation dynamics. The method of collecting data using a quasi-experimental design with an experimental procedure is One-Group-PretestPosttest Design. The data analysis technique used descriptive statistical calculations in pretest, posttest, and $\mathrm{N}$-gain scores. Besides, using different test paired sample t-test, effect size, and gfactor. The results other the pair results ed-sample t test showed-test the use of web-based assessment had a very large effect on students' mastery of concepts as indicated by the difference in the pretest and posttest scores. With the g-factor, there is the effectiveness of learning using a web-based assessment, and there is an increase in scores due to treatment, and students' initial ability does not influence it. With a correlation test for pretest and N-gain scores and a correlation test for pretest and posttest scores, web-based assessment effectively facilitates all students.
\end{abstract}

Keywords: understanding the concept, the web-based assessment, equilibrium and rotation dynamics

\section{INTRODUCTION}

Physics is a natural science branch that aims to develop students' analytical skills, understanding, and knowledge of the surrounding environment (Azizah, Yuliati, \& Latifah 2015). Physics subjects' objectives could be stated essentially achieved if students have a deep understanding and knowledge of physics concepts (Hastuti \& Rahardjo n.d.). Students' understanding of concepts will determine how students identify problems and determine problem-solving strategies (Yerushalmi, Cohen, Mason, \& Singh 2012). Understanding the idea in question is still contrary to students who only memorize concepts and do not know how to use them when facing a problem. This causes students to feel demanding when solving a physics problem. It is proven that Indonesian students' ability to solve physics problems is in a low category, which is on the 50th order out of a total of 57 countries or at level three of the six existing levels. This situation is preceded by reasons that significantly affect the ability of students.

Several things cause a lack of concepts understanding by the students in solving physics problems. First, students' inability to identify the issues cannot understand problems and solve them (Soong, Mercer, \& Er 2009). Second, students are often only given ready-made formulas without understanding the meaning of those formulas (Sayyadi \& Hidayat 2016). Therefore, when looking at some of these causes, understanding the concept is very important for students to train and solve various complex problems that are increasingly complex, especially issues in physics subjects (Laksmiari 2019). 
One way to improve students' conceptual understanding in solving physics problems is by implementing meaningful learning (Bakri et al. 2020). Meaningful physics learning can be done to assemble a complete experience and not easily forgotten. The teacher creates a component of teaching and learning to develop a meaningful understanding (Short \& Graham 2020). Still, it also requires unlimited effort support between teachers, students, tools, media, learning models, assesment, and facilities and infrastructure to support learning (Sugiyanto 2019). One of them is an assessment media. The use of well-designed and implemented assessments can improve understanding (Izci 2020), increase student competence, and provide the information needed by teachers and students to enhance the learning process. This causes teachers and students to improve the learning process and outcomes.

Apart from all that, there is one fact that cannot be denied. That fact is that today's world has challenges in which the technological era is developing very rapidly (Twining 2020). This is undoubtedly a challenge for teachers, including in applying technology to student assessment activities (Petra \& Aziz 2020). Technology-based assessments are generally found in the form of ComputerBased Tests (CBT) (Nissen 2018) and web-based (Kim \& Ryu 2013). One of the CBT-based evaluation weaknesses is that it must be done using a computer device (Nissen 2018), unlike the web-based assessment, which is more flexible because it can be used on various devices such as computers, laptops, and smartphones. However, a web-based evaluation requires that the user must have an internet connection. Based on APJII's survey, there are quite a lot of internet users in Indonesia (Irawan et al. 2020). At school age, students have a total of more than 2 million users (Irawan et al. 2020).

Therefore, in this study, the researchers tried to make an assessment based on an online or webbased assessment. This study's focus or purpose is to see the effectiveness of web-based assessments developed on the students' conceptual understanding of the equilibrium rotation dynamics material. In previous studies, there has been no research using web-based assessment media to see students' ability to understand concepts on equilibrium and rotation dynamics.

\section{METHODS}

This study used a quasi-experimental method. The results of the data analysis used quantitatively in nature, intending to test the predetermined hypothesis.

$\mathrm{H} 0$ = web-based assessment is not effective in increasing the students' conceptual understanding of equilibrium and rotation dynamics.

$\mathrm{Ha}=$ web-based assessment is effective in increasing students' conceptual understanding of equilibrium and rotation dynamics.

The experimental design used is One-Group-Pretest-Posttest Design, so it will be seen how the treatment effect in the form of a web-based assessment improves students' understanding of concepts in learning. The one group pretest-posttest design pattern is shown in TABLE 1 below.

TABLE 1. Research design One Grup Pretest-Posttest Design

\begin{tabular}{lccc}
\hline Group & Pretest & Treatment & Posttest \\
\hline Experiment & $\mathrm{O}_{1}$ & $\mathrm{X}$ & $\mathrm{O}_{2}$ \\
\hline
\end{tabular}

This research was conducted at SMAN 3 Pamekasan, which consisted of 45 students of class XI MIPA 6. The data collection instrument used was the concept mastery test. The data analysis technique used was obtained from the pretest, posttest, and N-gain scores. A paired sample t-test is used to determine whether there were differences in the students' mastery of concepts before and after the use of the web-based assessment. A paired sample t-test was performed on the average pretest and posttest scores. To find out how much increase between pretest and posttest scores due to treatment using the effect size. To be able to interpret the value of the effect size that has been obtained, whether it is small, medium, or large. It can be seen in TABLE 2.

TABLE 2. Guidelines for Providing Interpretation of the Effect Size Value

\begin{tabular}{cc}
\hline Relationship Level & Coefficient Interval \\
$0.00-0.199$ & Very Low \\
$0.20-0.399$ & Low \\
$0.40-0.599$ & Moderate \\
$0.60-0.799$ & Strong \\
$0.80-1$ & Very Strong \\
\hline
\end{tabular}


To determine the effectiveness of learning and the increase in student scores, many researchers use normalized gain analysis or g-factor (Coletta \& Phillips 2005; Hake 2014; Korff \& Rebello 2012; Waldrip \& Rusdiana 2012). The N-Gain criteria can be seen in TABLE 3.

TABLE 3. The N-Gain Criteria (Sutopo \& Waldrip 2014)

\begin{tabular}{cc}
\hline The Average Gain Scorer & Category \\
\hline$(\mathrm{g}) \geq 0.25$ & Low \\
$0.25 \leq(\mathrm{g})<0.45$ & Lower Medium \\
$0.45 \leq(\mathrm{g})<0.65$ & Medium \\
$(\mathrm{g})<0.65$ & High \\
\hline
\end{tabular}

A correlation test is used To reinforce the claim that web-based assessment is useful in facilitating all students. Also, a correlation test is carried out on the pretest and $\mathrm{N}$-gain scores achieved by each student and a correlation test for the pretest and posttest scores (Korff \& Rebello 2012).

\section{RESULTS AND DISCUSSION}

Web-based assessment is critical to use in learning when it refers to essential points of material and difficulties experienced by students. Students' problem is more to the concept that is not correct, so meaningful learning is needed to make students understand more deeply and make an impression when understanding the idea. Meaningful learning could be realized by involving students in education, making students both writers and evaluators (Gogoulou, Gouli, Grigoriadou, Samarakou, \& Chinou 2020). Students are said to be evaluators when students evaluate themselves on what they are doing to deepen the material that students have mastered indirectly. Students are said to be writers when students write what they understand/do not understand after/before reading the provided conceptual question feedback.

Students as evaluators and writers are poured into an assessment form designed with a website based public network (online assessment). Implementing online examinations will be more efficient in terms of time, funding, and assessment objectives (Sahidu \& Astutik 2017); (Conole \& Warburton 2005). In some universities in the United States, this kind of assessment is used as additional subjects that have been done after regular $r$ lectures hours. It doesn't interfere with the learning process in the classroom.

The components presented in the web-based assessment are in the form of conceptual question exercises consisting of 10 multiple choice questions for three meetings. The answers consist of the first-tier in the form of answer choices from the questions given, and second-tier reasons support students' answer choices. The second-tier questions' presentation made the students not just answer but required students to think about the reasons for the answers they chose. In understanding the fundamental concepts of rotation dynamics, a pattern is needed to differentiate between students who understand the idea and students who do not understand it. (Sutopo et al. 2017) suggested that the conceptual questions presented should be in the form of multi-context and multi-representational questions. In this study, the questions used in the assessment used a verbal representation format or pictures.

Furthermore, the in-depth study of the material is carried out by providing quick feedback (Henderson \& Harper 2009; Koenig, Endorf, \& Braun 2007; Salas-Morera, Arauzo-Azofra, \& GarcíaHernández 2012; Yerushalmi et al. 2012). Feedback given quickly will directly improve students' conceptions (Gladding, Gutmann, Schroeder, \& Stelzer 2015). Giving feedback will benefit students' learning activities, including (1) increasing learning motivation; (2) increasing self-confidence; (3) helping students to understand where the mistakes are; and (4) helping students to correct their mistakes; (5) individually correcting a wrong understanding and strengthening the correct understanding.

There is also a self-assessment in this web-based assessment, where students can express difficulties when solving problems. Later on, students themselves will find answers to these difficulties by looking at the discussion of questions. In the web-based assessment, the question presentation model is made with the theme "How to be a millionaire ", where students will not come out or continue to the next 
question until they answer the question correctly, assisted by an explanation of the material. So that in the end, students will try to read and understand the problems repeatedly, which causes students to be rich in knowledge or become science billionaires. When students frequently do the questions, the students will find it easier to understand learning physics. FIGURE 1, FIGURE 2, FIGURE 3, FIGURE 4 , is presented in the form of an example of a web-based assessment display.

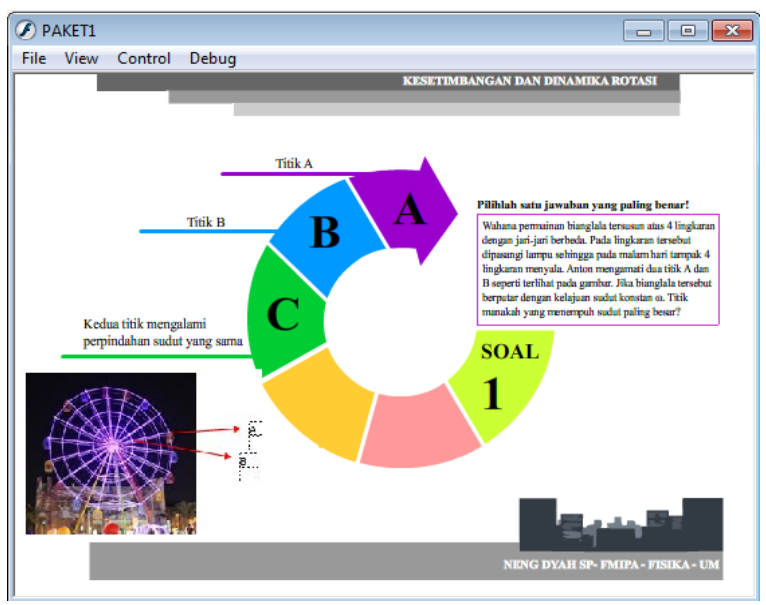

FIGURE 1. Example of a Tier-1 Web-Based Assessment Question Display

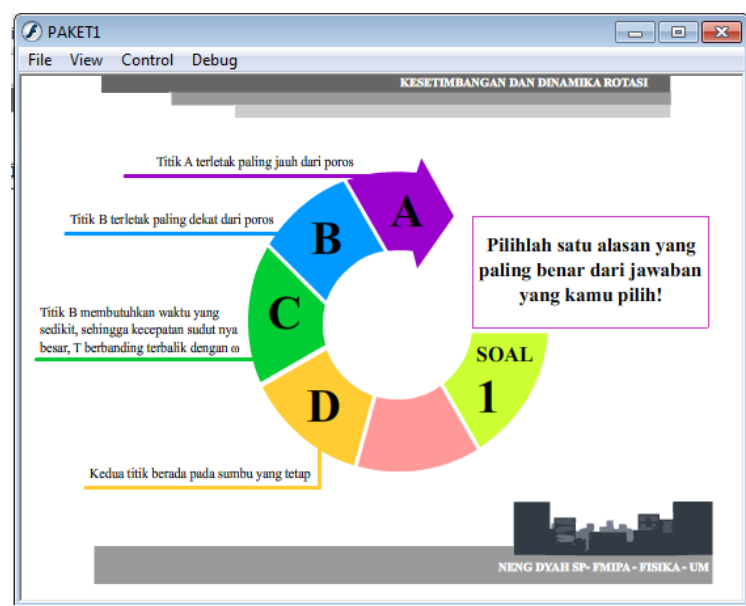

FIGURE 2. Example of a Tier-2 Web-Based Assessment Question Display

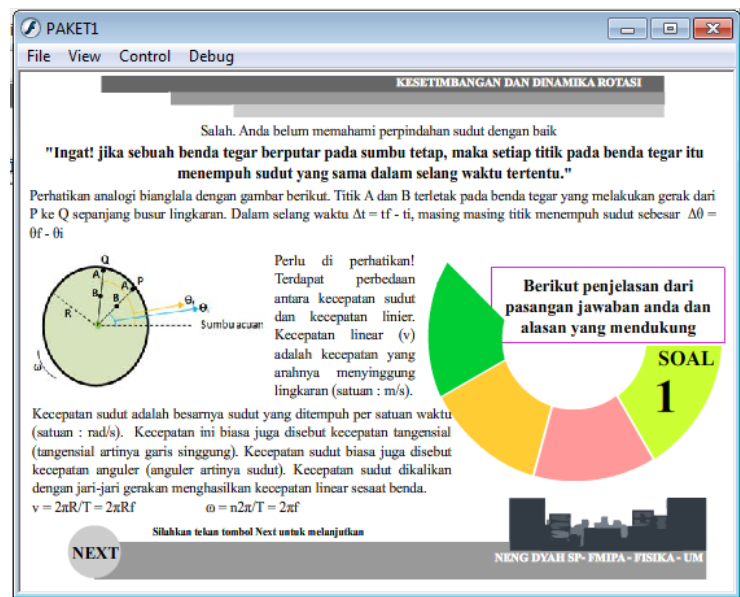

FIGURE 3. Example of Web-Based Assessment Feedback Display 


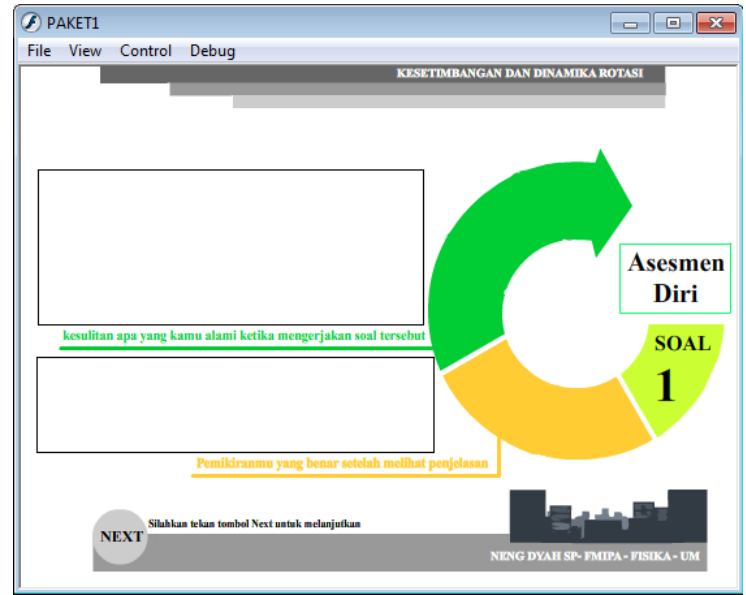

FIGURE 4. Example of Web-Based Assessment Self-Assessment Display

The paired sample t-test showed a significant difference in the mean score between the pre-test and post-test, $\mathrm{t}(\mathrm{df}=39)=13.015, \mathrm{p}=0.000 \mathrm{~d}=2.06$. seen that $\mathrm{p}=0.000<0.05$, then $\mathrm{H} 0$ is rejected. The post-test score (mean $=13,800)$ was higher than the pretest score $($ mean $=8.175)$. The value of the $d$ effect size $(\mathrm{d}=2.06)$ is included in the vast category. This means that, statistically, web-based assessments greatly affect students' mastery of concepts as indicated by the difference in pre-test and post-test scores.

To determine the effectiveness of learning and the increase in student scores, many researchers use normalized gain analysis or g-factor (Coletta \& Phillips 2005; Hake 2014; Korff \& Rebello 2012; Waldrip \& Rusdiana 2012). The $G$ - factor can be calculated through the normalized gain of the class mean $\langle g\rangle$ and the average of the normalized gain $\langle\bar{g}\rangle$. Distribution of gain values shown in FIGURE 5. The low category is worth 0.09091 with a frequency of $1,0.125$ with a frequency of $1,0.14286$ with a frequency of $2,0.16667$ with a frequency of 3 , and 0.2 with a frequency of 1 . The lower medium category has a value of 0.25 with a frequency of $14,0.27273$ with a frequency of 3.28571 with a frequency of $1,0.33333$ with a frequency of 16 , and 0.36364 with a frequency 2 . The medium category is worth 0.45455 with a frequency of 3.5 with a frequency of $14,0.57143$ with a frequency of 3 , and 0.6 with a frequency of 9 . The high category is worth 0.66667 with a frequency of 3 and 1 with a frequency of 7 . The calculation result $\langle g\rangle$ is obtained at 0.438 during the calculation $\langle g\rangle$ is obtained for 0.439 . The g-factor value is included in the lower medium category. This shows that the effectiveness of using web-based assessments can improve students' understanding of concepts.

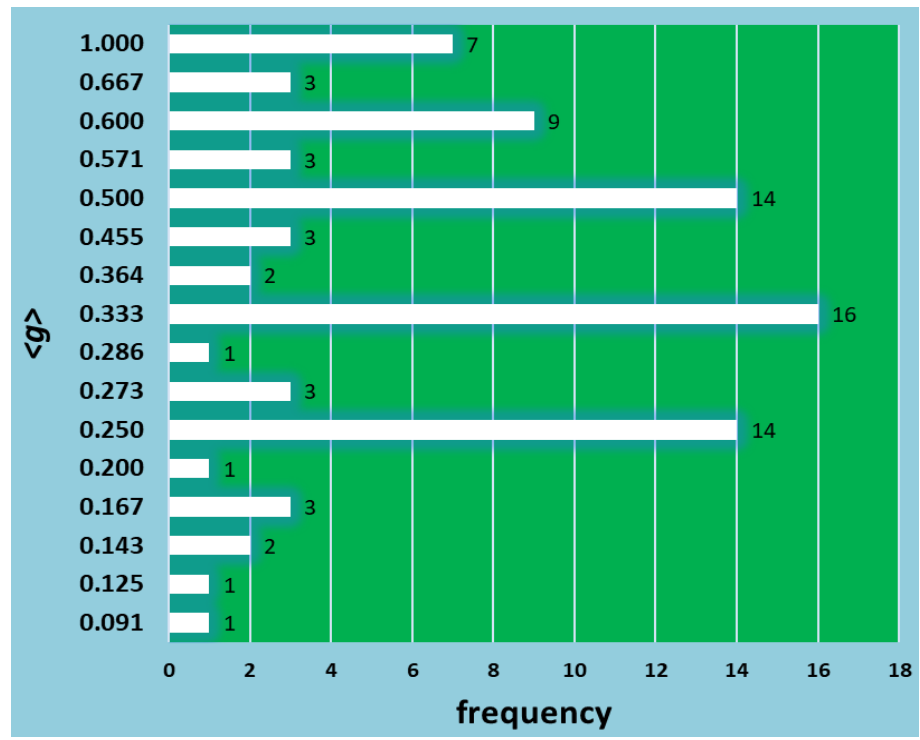

FIGURE 5. Distribution of gain values $\langle g\rangle$ 
The correlation test was carried out on the pre-test and N-gain scores achieved by each student and a correlation test on the pre-test and post-test scores (Korff \& Rebello 2012). The result showed there was no correlation between the pre-test and post-test scores with the N-gain achieved by each student, $\mathrm{p}=0.971$. The correlation test on the pre-test and post-test scores showed a significant correlation of $\mathrm{p}$ $=0.001$ with a high positive correlation value $r=0.502$. Thus, the web-based assessment is useful in facilitating all students.

The web-based assessment's effectiveness on students' conceptual mastery based on the difference in the pre-test and post-test scores above is measured using the same concept mastery test questions given in the pre-test and post-test. Therefore, the pre-test and post-test implementation in this study have a sufficient grace period to prevent students from working on pre-test questions by remembering post-test questions. In further research, it is recommended to use a different set of problems but with an equal level of difficulty during the pre-test and post-test to avoid students remembering the form of the pre-test questions when working on post-test questions.

\section{CONCLUSION}

The web-based assessment, which has been developed, is effective in improving students' mastery of concepts on equilibrium and rotation dynamics. This result could be seen from the pre-test and posttest scores. There was a very large difference in the category between score pre-test and post-test (deffect size $=2.06$ ) with a score of pros t-test higher pre-test. The pre-test increase to post-test scores was in the lower medium category, with the class normalized gain value of 0.438 . Moreover, this developed web-based assessment effectively facilitates all students to improve their mastery of the concept. Both students get high scores and low scores on the pre-test. All students experienced an equal gain in the score, indicated by the similarity between $\langle g\rangle$ and $\langle\bar{g}\rangle$. There was no correlation between the pre-test score and the gain achieved by each student.

\section{ACKNOWLEDGMENTS}

Thank you to the supervisor who has provided input and direction so that this article can be completed. Thank you to the Physics teacher and high school students who have helped and provided the opportunity to do research. Friends of S1 Physics Education offering $\mathrm{C}$ who have provided input and motivation in writing this article.

\section{REFERENCES}

Azizah, R, Yuliati, L, \& Latifah, E 2015, 'Kesulitan Pemecahan Masalah Fisika pada Siswa SMA', Jurnal Penelitian Fisika dan Aplikasinya (JPFA), vol. 5, no. 2, p. 44.

Coletta, VP, \& Phillips, JA 2005, 'Interpreting FCI scores: Normalized gain, preinstruction scores, and scientific reasoning ability', Am. J. Phys, vol. 73, no. 12, p. 11.

Conole, G, \& Warburton, B 2005, 'A review of computer-assisted assessment', Research in Learning Technology, vol. 13, no. 1.

Gladding, G, Gutmann, B, Schroeder, N, \& Stelzer, T 2015, 'Clinical study of student learning using mastery style versus immediate feedback online activities', Physical Review Special Topics Physics Education Research, vol. 11, no. 1, p. 10114.

Gogoulou, A, Gouli, E, Grigoriadou, M, Samarakou, M, \& Chinou, D 2020, 'A Web-based Educational Setting Supporting Individualized Learning', Collaborative Learning and Assessment, vol. 4, p. 16.

Hake, RR 2014, 'Interactive-engagement versus traditional methods: A six-thousand-student survey of mechanics test data for introductory physics courses', Am. J. Phys, vol. 66, no. 1, p. 12.

Hastuti, I, \& Rahardjo, DT 2011, 'Analisis Kesalahan Dalam Menyelesaikan Soal Materi Pokok Kalor Pada Siswa Kelas X Sma’, Jurnal Materi dan Pembelajaran, vol. 11. 
Henderson, C, \& Harper, KA 2009, 'Quiz Corrections: Improving Learning by Encouraging Students to Reflect on Their Mistakes', The Physics Teacher, vol. 47, no. 9, pp. 581-86.

Sutopo S, Jayanti, IBR, Wartono, W 2017, 'Efektivitas Program Resitasi Berbasis Komputer Untuk Meningkatkan Penguasaan Konsep Mahasiswa Tentang Gaya dan Gerak', Jurnal Inovasi dan Pembelajaran Fisika, vol. 4.

Koenig, KM, Endorf, RJ, \& Braun, GA 2007, 'Effectiveness of different tutorial recitation teaching methods and its implications for TA training', Physical Review Special Topics - Physics Education Research, vol. 3, no. 1, p. 10104.

Korff, J, Von, \& Rebello, NS 2012, 'Teaching integration with layers and representations: A case study', Physical Review Special Topics - Physics Education Research, vol. 8.

Laksmiari, K 2019, 'Kemampuan Pemecahan Masalah Siswa pada Pokok Bahasan Elastisitas dengan Menggunakan Model Pembelajaran Discovery Learning di SMAN 4 Jember', Prosiding Seminar Nasional Pendidikan Fisika.

Sahidu, H, \& Astutik, F 2017, 'Desain Sistem E-Assessment Pada Pembelajaran Fisika di LPTK', Jurnal Pendidikan Fisika dan Teknologi, vol. 3, no. 2, p. 6.

Salas-Morera, L, Arauzo-Azofra, A, \& García-Hernández, L 2012, 'Analysis Of Online Quizzes As a Teaching And Assessment Tool', Journal of Technology and Science Education, vol. 2, no. 1, pp. $39-45$.

Sayyadi, M, \& Hidayat, A 2016, 'Pengaruh Strategi Pembelajaran Inkuiri Terbimbing Dan Terhadap Kemampuan Pemecahan Masalah Fisika Pada Materi Suhu Dan Kalor Dilihat Dari Kemampuan Awal Siswa', Jurnal Inspirasi Pendidikan, vol. 6, p. 10.

Soong, B, Mercer, N, \& Er, SS 2009, ‘Students' Difficulties When Solving Physics Problems: Results from an ICT-infused Revision Intervention', Proceedings of the 17th International Conference on Computers in Education [CDROM], Hong Kong, vol. 5.

Sutopo, \& Waldrip, B 2014, 'Impact of a Representational Approach on Students', International Journal of Science and Mathematics Education, vol. 12, pp. 741-66.

Waldrip, B, \& Rusdiana, D 2012, 'Impact Of Representational Approach On The Improvement Of Students', Understanding of Acceleration, vol. 13.

Yerushalmi, E, Cohen, E, Mason, A, \& Singh, C 2012, 'What do students do when asked to diagnose their mistakes? Does it help them? I. An atypical quiz context', Physical Review Special Topics Physics Education Research, vol. 8, no. 2, p. 20109.

Bakri, F, et al. 2020, 'The Design of Physics Learning Video as Joyful-Based Learning Media Enrichment by Powtoon', Journal of Physics: Conference Series, vol. 1491, no. 012061.

Sugiyanto, et al. 2019, 'Analysis of infrastructure for integration of mobile learning and project based learning in technological and vocational education' J. Phys.: Conf. Ser., vol. 1402, no. 077041.

Irawan, AW, et al. 2020, Laporan Survei Internet Apjii 2019 - 2020 (Q2), Jakarta: APJII.

Short, CR, et al. 2018, 'Meaningful online learning: Integrating strategies, activities, and learning technologies for effective designs. Routledge', TechTrends, vol. 64, pp. 931-933.

Izci, K, et al. 2020, 'Exploring Effectiveness of Classroom Assessments for Students' Learning in High School Chemistry', Res Sci Educ vol. 50, pp. 1885-1916.

Twining, P, et al. 2020, 'Developing a quality curriculum in a technological era', Education Tech Research Dev.

Petra, TZHT \& Aziz, MJA, 2020, 'Investigating reliability and validity of student performance assessment in Higher Education using Rasch Model', J. Phys.: Conf. Ser., vol. 1529, no. 042088. 
Nissen, JM, et al. 2018, 'Participation and performance on paper- and computer-based low-stakes assessments', IJ STEM Ed, vol. 5, article number 21.

Kim, M, \& Ryu, J, 2013, 'The development and implementation of a web-based formative peer assessment system for enhancing students' metacognitive awareness and performance in illstructured tasks', Education Tech Research Dev, vol. 61, pp. 549-561. 